\title{
Psychometric evaluation of the Polish version of the Support in Intimate Relationships Rating Scale-Revised (SIRRS-R)
}

\author{
Michalina Ilska (D) A,B,C,D,E,F, Hanna Przybyta-Basista (DD $A, B, D, E, F$ \\ Institute of Psychology, University of Silesia, Katowice, Poland
}

\section{BACKGROUND}

Researchers are interested in studies on the importance of partner support for both the well-being of the individual in various life contexts and the marital satisfaction. The current study examined the psychometric properties of the Support in Intimate Relationships Rating Scale - Revised (SIRRS-R) developed by Barry, Bunde, Brock, and Lawrence with a Polish sample.

\section{PARTICIPANTS AND PROCEDURE}

The sample consisted of a total of 574 people in close heterosexual relationships, diverse in terms of age, sex, and education. Half of the participants were married and the other half in informal relationships, cohabiting with their partners. The duration of the relationship varied, with the average of 7 years.

\section{RESULTS}

The results of the present research indicate satisfactory psychometric properties of the Polish version of the
SIRRS-R. Our findings confirm the four-factor structure of support received from the partner proposed in the original version of the SIRRS-R. The questionnaire consists of four subscales: emotional and esteem support, informational support, physical comfort, and instrumental or tangible support. The Cronbach's $\alpha$ reliability for the whole scale is .94 (for the subscales it ranged from .85 to .92 ).

\section{CONCLUSIONS}

The Polish version of the SIRRS-R is a valid and reliable questionnaire suitable for use in research on the importance of partner support for physical and mental health of individuals in many contexts of life associated with stress, and for identifying factors contributing to marital satisfaction.

\section{KEY WORDS}

psychometric properties; questionnaire; partner support; received social support

CORResPonding Author - Prof. Hanna Przybyła-Basista, Institute of Psychology, University of Silesia, 53 Grażyńskiego Str., 40-126 Katowice, Poland, e-mail: hanna.przybyla-basista@us.edu.pl Authors' Contribution - A: Study design - B: Data collection - C: Statistical analysis - D: Data interpretation .

E: Manuscript preparation · F: Literature search · G: Funds collection

to Cite this ARTICle - Ilska, M., \& Przybyła-Basista, H. (2020). Psychometric evaluation of the Polish version of the Support in Intimate Relationships Rating Scale - Revised (SIRRS-R). Current Issues in Personality Psychology,

8(2), 139-153. 


\section{BACKGROUND}

Having close, supportive ties with others can have a significant positive effect on health, physiological response to psychological stressors (including better functioning of the immune system and reduced cardiovascular reactivity), coping with illness and stress, and promoting longevity (for reviews, see Dickerson \& Zoccola, 2011; Uchino, 2006). Researchers have focused on the importance of social support for the functioning of individuals in many contexts of family life associated with stress, such as coping with serious illness and recovering (Luszczynska, Boehmer, Knoll, Schulz, \& Schwarzer, 2007; OgińskaBulik, 2013; Schwarzer \& Knoll, 2007), coping with aging (Acitelli \& Antonucci, 1994; Cutrona, Russell, \& Rose, 1986), dealing with the consequences of divorce and successfully adjusting to post-divorce life (Amato, 2000; Kołodziej-Zaleska \& Przybyła-Basista, 2016), bringing up children with special needs or disabilities (Barnett, Clements, Kaplan-Estrin, \& Fialka, 2003; Findler, Jacoby, \& Gabis, 2016; Kózka \& Przybyła-Basista, 2018), and functioning of women during pregnancy and the postpartum period (DunkelSchetter, Sagrestano, Feldman, \& Killingsworth, 1996; Ilska \& Przybyła-Basista, 2017; Maliszewska, Bidzan, Świątkowska, \& Preis, 2016; Rini, Dunkel-Schetter, Hobel, Glynn, \& Sandman, 2006; Negron, Martin, Almog, Balbierz, \& Howell, 2013). In all these contexts of overcoming life's hardships, social support can prove crucial for ensuring health and well-being, as well as finding effective ways of coping with stress. The abundance of opportunities to analyze the mechanism of the impact of social support on the individuals' quality of life (main effect, stress-buffering effect or mediating effect - Cohen \& Wills, 1985; Cohen, 2004) is still an inspiration for researchers dealing with physical and mental health.

In this article, we will first review the literature on the importance of partner support in close relationships, and then focus on the description of a tool for measuring support received from the partner (SIRRS-R) in the original and Polish versions.

\section{PARTNER SUPPORT IN CLOSE RELATIONSHIPS}

The spouse is a key source of support in close relationships and often the person from whom support is sought first during crises (Cutrona, 1996a; Knoll \& Schwarzer, 2012). Moreover, there is also evidence suggesting that support from other sources may not replace the lack of marriage support or partner support in an intimate relationship (for review, see $\mathrm{Cu}$ trona, 1996a). Social support received from a partner is particularly important in experiencing adversity, stress or crisis (Gardner \& Cutrona, 2004), but it is also important when there are no particular obstacles in life and no adversities (although the research on the latter issue is very limited) (Feeney \& Collins, 2015).

The benefits of a supportive marriage have been the subject of numerous studies, proving not only the benefits for the physical and mental well-being of each of the spouses, but also indicating that supporting activities enrich the relationship and help maintain the marriage (Cutrona, 1996a). Partner support acts as a predictor of quality and durability of the partnership (Kiecolt-Glaser \& Newton, 2001; Kurdek, 2005). For marital satisfaction, the ability to provide partner support in various everyday situations is of great importance (e.g., Sullivan, Pasch, Eldridge, \& Bradbury, 1998; Kurdek, 2005). People who receive more support from a partner are more satisfied with their relationship than those who receive less support (e.g., Acitelli \& Antonucci, 1994). There exist differences between wives and husbands in the perception of the significance of the supporting behavior of the spouse, which affects the assessment of marriage. The perceived adequacy of support was a stronger predictor of marital satisfaction for husbands as opposed to the amount of support. In turn, the amount of support was a much stronger predictor of marital satisfaction for wives (Lawrence et al., 2008).

Cutrona (1996b) describes four different mechanisms of the impact of social support on the quality of the marital relationship: (a) emotional support from the partner can prevent emotional withdrawal or the feeling of isolation in marriage in time of severe stress, (b) partner's support can prevent the spouse's depression, which can have a negative effect on marriage; (c) support may prevent emerging conflicts from escalating; and (d) supportive communication associated with emotional intimacy can strengthen the bond between partners. The importance of partner support for maintaining a good relationship between spouses requires further research in order to understand what circumstances make it difficult for partners to support each other, what kinds of support are needed by men and women (Gardner \& Cutrona, 2004), and how inadequate forms of partner support (lacking vs. excessive) affect marital satisfaction (Brock \& Lawrence, 2009).

\section{CONCEPTUALIZATION OF SOCIAL SUPPORT: RECEIVED SUPPORT AND ITS MEASURES}

According to Cutrona (1996a, p. 10) "social support is conceptualized most generally as responsiveness to another's needs and, more specifically, as acts that communicate caring; that validate the other's worth, feelings, or actions; or that facilitate adaptive coping with problems through the provision of information, assistance, or tangible resources". The researchers analyze two main types of support: perceived available support and actual received support (Collins, Dunkel-Schetter, Lobel, \& Scrimshaw, 1993; Schwar- 
zer \& Knoll, 2007; Schwarzer \& Leppin, 1991; Prati \& Pietrantoni, 2010; Uchino, Carlisle, Birmingham, \& Vaughn, 2011). Perceived available support is anticipatory, while received support refers to the actual behavior of the person constituting the source of support that took place at a particular time (Collins et al., 1993). Although researchers expected the two forms of support to be closely related, the results did not confirm this assumption. Measuring both constructs showed that perceived support was only weakly correlated with the actual support received in specific situations (Dunkel-Schetter \& Bennett, 1990; see also Collins et al., 1993; Haber, Cohen, Lucas, \& Baltes, 2007) or the two types of support were completely different constructs (see Uchino, 2009; Uchino et al., 2011). The lack of consistency in the results raises questions about the connections between these constructs and their relationship with physical and mental health (Haber et al., 2007; Melrose, Brown, \& Wood, 2015). Research shows that, while perceived support is usually strictly related to health, the results regarding the relationship between received support and health are inconsistent (Melrose et al., 2015). Some researchers point to beneficial effects of received support (Collins et al., 1993), while others claim the effects to be negligible, or even report a negative relationship (Melrose et al., 2015; Uchino, 2009).

This article is concerned with the support received from the partner in an intimate relationship. Researchers generally agree that received support is a complex phenomenon (Rini et al., 2006; Barry, Bunde, Brock, \& Lawrence, 2009). While measurement of perceived available support refers to the general perception or belief that people with whom one has an intimate relationship will probably provide help in a time of need (Collins et al., 1993; see also Buszman \& Przybyła-Basista, 2017), received support refers to specific supporting behaviors that actually occur at an identifiable time and context. Thus, the measure of received support is the quantity of supportive behaviors received by an individual (Haber et al., 2007; Melrose et al., 2015). When measuring the received support, the individual is asked to report how exactly the supportive person has behaved recently (Collins et al., 1993).

The growing interest in research on the support received from a partner in a marital or informal relationship was the reason for further search for an appropriate measurement tool. An interesting option was found in the Support in Intimate Relationships Rating Scale - Revised (SIRRS-R) developed by Barry, Bunde, Brock, and Lawrence (2009). We decided to adapt this particular questionnaire to the Polish conditions for several reasons. Firstly, as we have already shown, a large body of research indicates that received partner support in intimate relationships plays an important role for personal health and well-being (e.g., Uchino, 2009) and also for quality of relationships (e.g., Cutrona, 1996a; Lawrence et al., 2008; Kielcot-
Glaser \& Newton, 2001). Therefore, validation of the Polish version of the SIRRS-R could yield a valuable tool for Polish researchers, who currently have only a few measures to investigate the problem of partner support. Secondly, the SIRRS-R questionnaire developed by Barry et al. (2009) makes it possible to capture the diversity and specificity of support provided by the partner in a close relationship (e.g. "Hugged me or cuddled with me"; "Patted or stroked me affectionately"). Other questionnaires do not provide such possibilities. For example, the subscale of the Received Social Support of the Berlin Social Support Scales (see BSSS developed by Schulz \& Schwarzer, 2003 or the Polish version of BSSS by Łuszczyńska, Kowalska, Mazurkiewicz, \& Schwarzer, 2006) allows for the assessment of two support types: emotional and instrumental. However, the items may refer to any person who provides support ("This person encouraged me not to give up"). The subscale Received Support of the BSSS questionnaire is most often used in research related to health, illness and coping with stressful events (e.g., Scholz, Ochsner, Hornung, \& Knoll, 2013). The SIRRS-R seems to have wider application, not only to couples experiencing adversity but also in the context of achieving marital satisfaction, favoring the durability of the partnership (Brock \& Lawrence, 2009).

While analyzing research reports (Barry et al., 2009; Brock et al., 2014), we also recognized the following advantages of the questionnaire: (a) multidimensional model of partner support and the possibility of measuring four basic types of support (emotional/esteem support, physical comfort, informational support, and tangible or instrumental support), (b) each of the types of support indicated links with marital adjustment, and with symptoms of depression and anxiety, (c) research validation was conducted among couples in close relationships (married and dating couples).

Our intention was to increase the number of resources available for measuring support received from the partner. The purpose of the present investigation was to develop a Polish version of the Support in Intimate Relationships Rating Scale - Revised (SIRRS-R; Barry et al., 2009) and evaluate its psychometric properties.

\section{POLISH ADAPTATION OF THE SUPPORT IN INTIMATE RELATIONSHIPS RATING SCALE - REVISED (SIRRS-R)}

\section{ASSESSMENT OF PARTNER SUPPORT: ORIGINAL VERSION OF SIRRS-R}

The Support in Intimate Relationships Scale - Revised (SIRRS-R) developed by Barry et al. (2009) is an adapted version of the SIRRS (Dehle, Larsen, \& Landers, 2001). The SIRRS-R questionnaire measures the global 
perception of support received from the partner in a close relationship in a given period of time (e.g., a given month), whereas in the original version of the SIRRS the measurement is taken every day for seven consecutive days. The SIRRS-R contains 25 items and is a shortened version of the original SIRRS questionnaire, which consisted of 48 items. When comparing these measurement tools, it should be emphasized that the original version of the SIRRS has a one-factor structure, while the SIRRS-R has a four-factor structure. Barry et al. (2009) assumed that received support is a multidimensional phenomenon that includes various types of support. The basis for their consideration of the social support structure was the multidimensional model proposed by Cutrona and Russell (1990), which includes five types of support: emotional support (providing comfort, assurance of love, friendship and devotion, providing a sense of security and belief that others do care), esteem support (strengthening the sense of competence and self-esteem), instrumental or tangible support (providing direct or indirect help in dealing with stressful situations - e.g., financial and physical assistance), informational support (providing information, giving advice), and network support or social integration (encouraging engagement in various forms of social activities, encouraging the use of family support network, friends).

Barry et al. (2009) tested the factor structure of received partner support several times, namely: one-factor structure (i.e., a unidimensional conceptualization of support), five-factor structure (proposed by Dehle for the original SIRRS questionnaire but not tested empirically) and finally a four-factor structure composed of emotional and/or esteem support, tangible support, informational support and physical comfort, the latter being a new factor as compared with Cutrona and Russell (1990). This four-factor structure turned out to be the best-fit model. Barry et al. (2009) stated that from the four factors, three of them - emotional and/ or esteem support, tangible support, and informational support - were among those listed by Cutrona and Russell (1990). They also found that received emotional support and esteem support were not two separate factors but constituted one common factor.

The new factor "physical comfort" resulted from the confirmatory factor analysis by Barry et al. (2009). "Physical comfort", containing statements such as (he or she) "kissed me" or "held my hand", emerged as a separate factor independent of the "emotional support” factor. At the same time, Barry et al. (2009) did not confirm that the "network support" mentioned by Cutrona and Russell (1990) was a separate factor. It was not a clear type of support and demonstrated relatively poor reliability. In conclusion, Barry et al. (2009) suggested that "network support" should be removed from the concept of the structure of support received from the partner, as proposed by Cutrona and Russell (1990).
The SIRRS-R shows good psychometric properties: strong reliability (internal consistency, factorial fit) and validity (see Barry et al., 2009). Cronbach's $\alpha$ was .95 for the entire scale, and from .87 to .92 for individual subscales (see also Brock et al., 2014). In order to obtain the scores of the support received from the partner, the answers referring to the estimated frequencies of supportive behaviors during the last month should be summed up $(0$ - never, 1 - rarely, 2 - sometimes, 3 - often, 4 - almost always). Participants are asked how often their partner engaged in each supportive behavior described in the questionnaire (SIRRS-R). The scores of received support can be calculated for the whole scale and separately for each type of support (Barry et al., 2009).

\section{POLISH VERSION OF SIRRS-R}

The aim of our study was to create the Polish version of the 25-item original English version of the SIRRS-R (Barry et al., 2009). Specific objectives were: (a) to examine the factor structure of the SIRRS-R by means of confirmatory factor analysis (CFA); (b) to validate the SIRRS-R questionnaire with external criteria (marriage satisfaction rating), and (c) to present a report of the psychometric properties of the SIRRS-R. We assumed that the Polish version of the questionnaire would have the same four-factor structure as the original version of the SIRRS-R. According to the methodological procedures used in the adaptation of the psychological tests (Hornowska \& Paluchowski, 2004) and after obtaining consent from the authors (Robin A. Barry), the SIRRS-R questionnaire was translated into Polish by five independent translators. Then an expert panel (i.e., seven English-speaking researchers with experience in the field of family psychology) developed a Polish version of items trying to make only minor necessary modifications not departing from the original statements. We tried to make the translation as exact as possible. Such a procedure made it possible to check the accuracy of the translation (Hornowska \& Paluchowski, 2004). Then, a pilot study was carried out.

\section{PARTICIPANTS AND PROCEDURE}

\section{PARTICIPANTS}

Studies on the Polish adaptation of the SIRRS-R were carried out from February 2016 to July 2017. A cross-sectional study design was used. Participants were recruited using the method of snowball sampling. To participate in the study, women and men had to be married or in informal relationships and aged above 18 years. The sample consisted of $N=574$ adults aged 19 to 64 years $(M=28.46, S D=7.79)$. 
All research participants were in heterosexual relationships: a half in marriages $(49 \% ; n=281)$, and the other half in informal relationships, cohabiting with their partner $(50.35 \% ; n=289)$. The duration of the relationship was varied, with the average of 7 years $(M=6.82, S D=6.16)$. The vast majority of the respondents were women ( $n=407 ; 70.90 \%)$, while men accounted for about one third of the research group ( $n=167 ; 29.10 \%)$. Participants with university level education constituted almost a half of the sample $(n=273 ; 47.60 \%)$, followed by those still studying ( $n=170 ; 29.60 \%)$, those having secondary education $(n=85 ; 14.80 \%)$, those having vocational $(n=21 ; 3.70 \%)$, post-secondary $(n=18 ; 3.10 \%)$ and primary education $(n=5 ; 0.9 \%)$. The Polish sample was very homogeneous with regard to race and ethnicity. The vast majority of participants completed paper/pencil questionnaires; only approximately one quarter $(n=141 ; 25.77 \%)$ completed the questionnaires online. The respondents were informed about the purpose of the study and agreed to participate. The instruction assured them of the voluntary nature of participation as well as anonymity.

\section{MEASURES}

The following measurement tools were used in the present research:

The Support in Intimate Relationships Rating ScaleRevised (SIRRS-R). The Polish version of the SIRRS-R (in Polish: Skala Oceny Wsparcia w Bliskich Zwiaz$k a c h)$ is a self-report questionnaire of 25 items that are evaluated on a 5-point Likert scale ranging from 0 (never) to 4 (almost always). The Polish version was prepared in accordance with the above-described principles and is included in the appendix (see Appendix - SIRRS-R in Polish/English version).

The Polish version of the Berlin Social Support Scales (BSSS - developed by Schulz \& Schwarzer, 2003 and adapted to Polish by Łuszczyńska et al., 2006). Received partner support was assessed using one of the subscales (Actually Received Social Support). This subscale consists of 15 items, including statements such as: "This person is feeling bad", "This person encouraged me to give up". Responses ranged from 1 (completely untrue) to 4 (completely true). Higher scores indicated higher received partner support. In the current study Cronbach's $\alpha$ was .93.

The Life Satisfaction Questionnaire (Fragebogen zur Lebenszufriedenheit [FLZ] by Fahrenberg, Myrtek, Schumacher, \& Brähler; see Polish adaptation by Chodkiewicz, 2009). The questionnaire comprises 10 subscales. We used one of them, namely "Satisfaction with Marriage/Relationship”. The subscale consists of seven items, including statements such as: "I am satisfied with the gentleness and support that my partner shows me", "I am satisfied with the hon- esty and openness in our relationship". Responses are evaluated on a 7-point scale from 1 (very dissatisfied) to 7 (very satisfied). The higher the score, the greater the marriage/relationship satisfaction. In our study Cronbach's $\alpha$ was .95 .

\section{RESULTS}

\section{FACTORIAL STRUCTURE OF RECEIVED SUPPORT}

Statistical analyses of the collected results were performed using the PS Imago program - SPSS Statistic 24 and JASP 0.11.1 equipped with the lavaan package (Rosseel, 2012). In order to verify the factor structure of the original SIRRS-R version, a confirmatory factor analysis (CFA) was performed using a DWLS estimator (diagonally weighted least squares, i.e., estimation procedure for categorical variables with both multivariate normal and non-normal distributions - Mîndrilă, 2010). The DWLS methods worked well in many conditions, including smaller samples and non-normal data (Rhemtulla, Brosseau-Liard, \& Savalei, 2012). The dimensionality of the SIRRS-R was investigated using conventional CFA techniques, along with the utilization of a higher-order structure of a CFA measurement model (see Brown, 2006; Januszewski, 2011).

We tested the factor structure of the SIRRS-R several times. First, we tested a one-factor model (model 1 - see Table 1), and then a four-factor model (model 2 - see Table 1). Model 2 has proven to be an intercorrelated four-factor solution (see Figure 1) measuring informational support (8 items; factor Fc1 contains items $1,2,3,4,5,6,7,8)$, physical comfort (4 items; factor Fc2 contains items 9, 10, 11, 12), emotional/esteem support ( 8 items; factor Fc3 includes items $13,14,15,16,17,18,19,20)$, and instrumental/ tangible support ( 5 items; factor Fc4 consists of items $21,22,23,24,25)$ proposed by Barry et al. (2009). The factors in our analysis were given the same names as in the original version of the SIRRS-R. We also tested a third model (model 3). This model is a second-order factor conceptualization to determine whether the four factors could be explained by a broader general factor, which we assumed to be "Support in Intimate Relationship" (see Figure 2).

We employed CFA to compare the three competing models and determine the best-fitting factor model (Table 1). Regular $\chi^{2}$ difference tests were not conducted here for the comparison of non-nested competing models. Following generally accepted practice, we used the Tucker-Lewis index (TLI), the $\chi^{2}$ statistic, comparative fit index (CFI), and root mean square error of approximation (RMSEA) to evaluate the fit of each model. CFI and TLI values $\geq .90$ indicate adequate model fit (.95, excellent fit), 


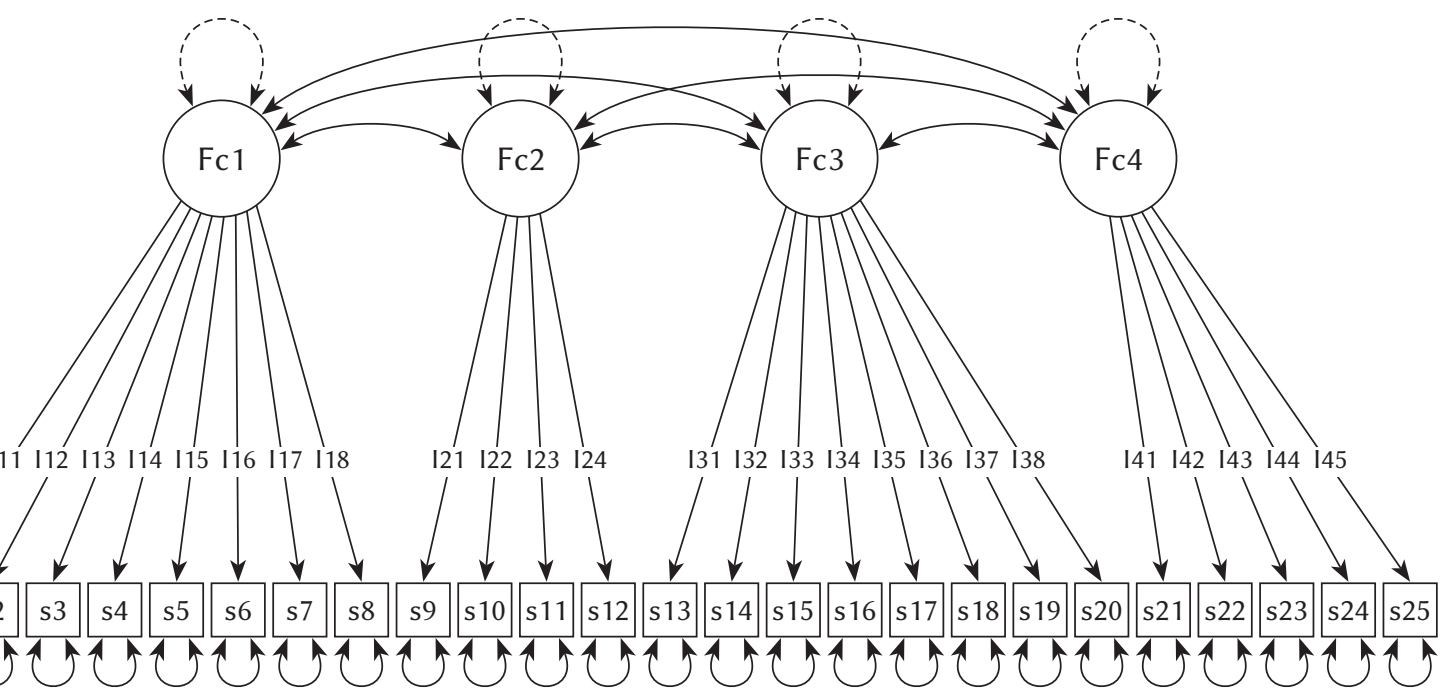

Figure 1. Hypothesized model of four-factor structure for the SIRRS-R.

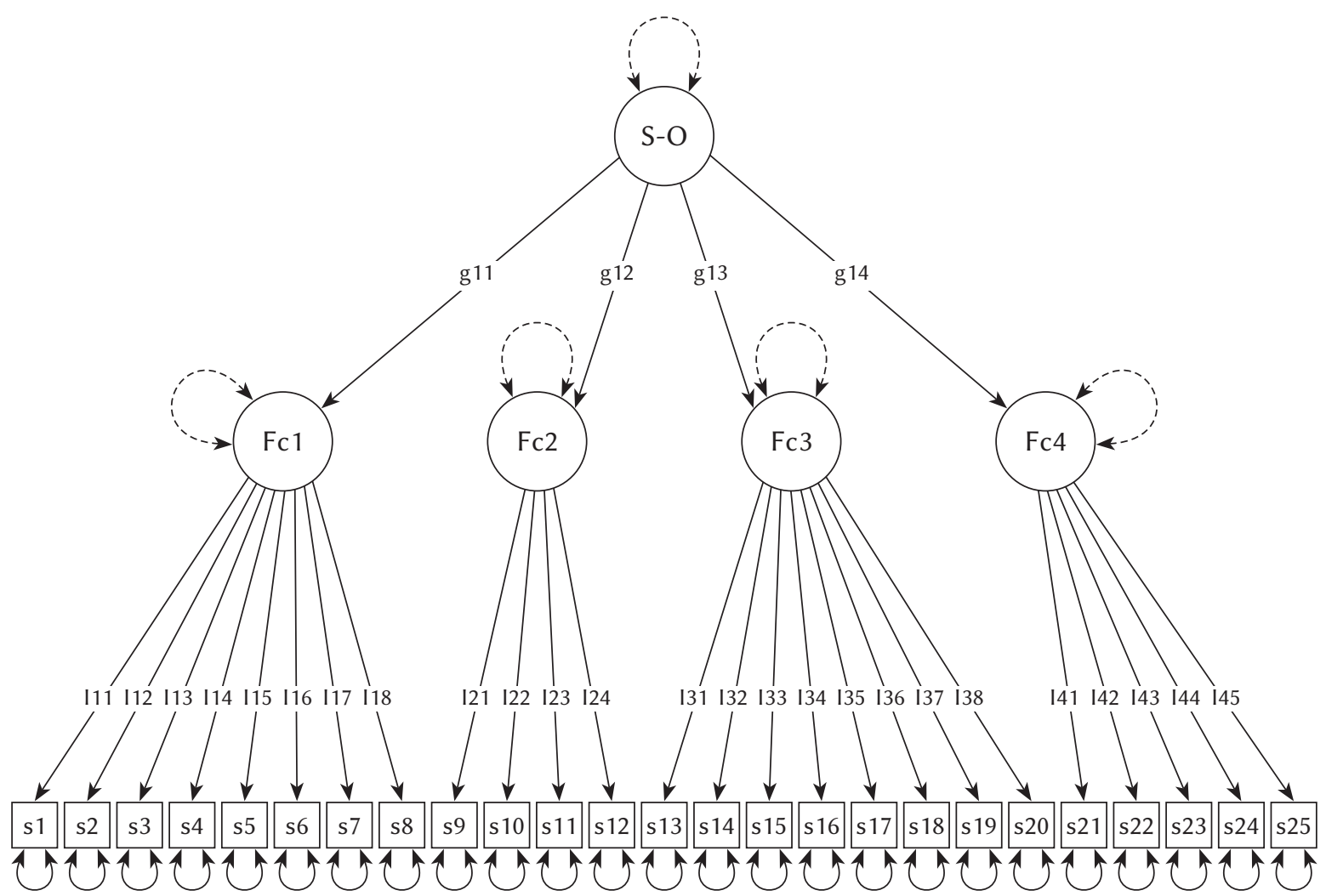

Figure 2. Hypothesized second-order model of factorial structure for the SIRRS-R.

Table 1

Confirmatory factor analysis (CFA) and second-order model fit indices for the alternative models of the SIRRS-R

\begin{tabular}{lccccc}
\hline CFA models & $\chi^{2}$ & $d f$ & CFI & TLI & RMSEA \\
\hline Model 1 (1-factor) & $1007.02^{*}$ & 275 & .967 & .964 & $.068(.064-.073)$ \\
Model 2 (4-factor) & $470.23^{*}$ & 269 & .991 & .990 & $.036(.031-.042)$ \\
Model 3 (second-order factor) & $477.69^{*}$ & 271 & .991 & .990 & $.036(.031-.042)$ \\
\hline
\end{tabular}

Note. $\mathrm{N}=574$; CFI - comparative fit index; TLI - Tucker-Lewis index; RMSEA - root-mean-square error of approximation; $\mathrm{Cl}$ - confidence interval; ${ }^{*}$ indicates $\chi^{2}$ is statistically significant $(p<.001)$. 
while RMSEA values $\leq .08$ and .06 indicate acceptable and excellent fit, respectively.

Table 1 reports the fit indices for the three alternative models. We obtained good fit indices in all examined models. CFIs, TLIs, and RMSEAs were $>.95,>.95$, and $<.04$, respectively. The one-factor model (model 1) has the weakest fit from the three presented models $\left(\chi^{2}=1007.02, d f=275\right.$, TLI $=.964$, CFI $=.967$, RMSEA $=.068)$.

The best-fitting model is the Barry four-factor model $\left(\chi^{2}=470.23, d f=269\right.$, TLI $=.990$, CFI $=.991$, RMSEA $=.036)$. The results of first-order CFA showed that the four-factor model has a good fit to the data (Table 1). The adequacy of this model must also be considered in terms of the parameter estimates: all the factor loadings were high, positive, and statistically significant. The covariances between factors are high (.64-.85), but between two factors (factor 1 and factor 3 ) they are too high (.85). That may mean poor discriminant validity (Brown, 2006). If all factors are moderately intercorrelated at roughly the same magnitude, a single higher-order factor may account for these relationships (Brown, 2006, p. 32). We hypothesized that there is a higher-order factor in the SIRRS-R that accounts for the commonality among first-order factors. As can be seen from Table 1, the second-order model has almost the same fit indices as the first-order model $\left(\chi^{2}=477.69, d f=271\right.$, TLI $=.990$, CFI $=.991$, RMSEA $=.036$ ). The second-order factor explains a high percentage of variance for scores in informational support $\left(R^{2}=.81\right)$ and emotional/esteem support $\left(R^{2}=.89\right)$ and a moderate percentage of variance for instrumental/tangible support $\left(R^{2}=.68\right)$ and physical comfort $\left(R^{2}=.42\right)$. Standardized factor loadings for the second-order CFA are included in Table 2. The adequacy of this model can also be determined in relation to its parameter estimates. All the factor loadings for the general factor of the SIRRS-R are high, positive, and statistically significant $(p<.001)$ (see Table 2$)$.

The psychometric properties of the scale are satisfactory (see Hornowska \& Paluchowski, 2004). Reliability for the whole scale measured by Cronbach's $\alpha$ equals .94 , which is fully satisfactory. The internal consistency measured by Cronbach's $\alpha$ for individual subscales is satisfactory as well, being .87 for informational support, .92 for physical comfort, .88 for emotional and esteem support, and .85 for instrumental or tangible support. It is assumed that the $\alpha$ value of .70 and above indicates a satisfactory reliability of the measured scale (Bedyńska \& Cypryańska, 2013).

\section{TESTING OF 4-FACTOR MODEL ACROSS MARITAL AND INFORMAL RELATIONSHIPS}

We tested the proposed four-factor model to determine whether it fits the empirical data from the
Table 2

Standardized second-order factor loadings for the four grouping factors of the SIRRS-R

\begin{tabular}{|c|c|c|}
\hline Construct & Item & $\beta$ \\
\hline \multirow[t]{4}{*}{$\begin{array}{l}\text { Support in Intimate } \\
\text { Relationship }\end{array}$} & $\begin{array}{l}\text { Informational } \\
\text { support }\end{array}$ & .90 \\
\hline & Physical comfort & .65 \\
\hline & $\begin{array}{l}\text { Emotional/esteem } \\
\text { support }\end{array}$ & .95 \\
\hline & $\begin{array}{l}\text { Instrumental/ } \\
\text { tangible support }\end{array}$ & .83 \\
\hline \multirow{8}{*}{$\begin{array}{l}\text { Informational } \\
\text { support }\end{array}$} & sirrs 1 & .69 \\
\hline & sirrs 2 & .70 \\
\hline & sirrs 3 & .70 \\
\hline & sirrs 4 & .57 \\
\hline & sirrs 5 & .60 \\
\hline & sirrs 6 & .68 \\
\hline & sirrs 7 & .68 \\
\hline & sirrs 8 & .74 \\
\hline \multirow[t]{4}{*}{ Physical comfort } & sirrs 9 & .88 \\
\hline & sirrs 10 & .89 \\
\hline & sirrs 11 & .83 \\
\hline & sirrs 12 & .83 \\
\hline \multirow{8}{*}{$\begin{array}{l}\text { Emotional/esteem } \\
\text { support }\end{array}$} & sirrs 13 & .69 \\
\hline & sirrs 14 & .74 \\
\hline & sirrs 15 & .58 \\
\hline & sirrs 16 & .75 \\
\hline & sirrs 17 & .71 \\
\hline & sirrs 18 & .73 \\
\hline & sirrs 19 & .70 \\
\hline & sirrs 20 & .63 \\
\hline \multirow{5}{*}{$\begin{array}{l}\text { Instrumental/ } \\
\text { tangible support }\end{array}$} & sirrs 21 & .79 \\
\hline & sirrs 22 & .81 \\
\hline & sirrs 23 & .65 \\
\hline & sirrs 24 & .58 \\
\hline & sirrs 25 & .81 \\
\hline
\end{tabular}

Note. All factor loadings are statistically significant $(p<.001)$

sample of participants in informal relationships and married couples. CFAs of our four-factor structure adequately fit the data from participants in informal relationships: $\chi^{2}=287.95, d f=269 ; p=.204$; TLI $=.998$, 
$\mathrm{CFI}=.998, \mathrm{RMSEA}=.016$ (second-order factor model: $\chi^{2}=292.82, d f=271, p=.173, \mathrm{TLI}=.998, \mathrm{CFI}=.998$, RMSEA $=.017$ ), and married couples: $\chi^{2}=291.40$, $d f=269, p=.166, \mathrm{TLI}=.998, \mathrm{CFI}=.998, \mathrm{RMSEA}=.017$ (second-order factor model: $\chi^{2}=295.61, d f=271$, $p=.146, \mathrm{TLI}=.998, \mathrm{CFI}=.998$, RMSEA $=.018)$. This suggests that the model fits both the individuals in informal relationships and married participants. In other words, the four-factor model of partner support is valid in both groups.

\section{CONSTRUCT VALIDATION OF THE POLISH VERSION OF THE SIRRS-R}

The analysis of the inter-correlation matrix demonstrates that the subscales included in the SIRRS-R questionnaire distinguished on the basis of factor analysis remain interrelated (Table 3 ). The correlations between individual subscales and the global score for the entire scale are statistically significant and high. These interdependencies remain in accord with the expectations and confirm the internal validity of the SIRRS-R questionnaire.

Convergent validity was confirmed using another measurement tool for received support. Correlations were calculated between the SIRRS-R scores and the Actually Received Social Support subscale, a part of the Polish version of the Berlin Social Support Scales (BSSS - Łuszczyńska et al., 2006). As expected, the correlations proved to be significant, positive and high (for the overall SIRRS-R score, $r=.89, p<.01$ ). In addition, the relationship between SIRRS-R and Satisfaction with Marriage/Relationship (one of the Life Satisfaction Questionnaire subscales of the Polish adaptation by Chodkiewicz, 2009) was evaluated. Both the results for the entire SIRRS-R scale and its four subscales were significantly, positively and usually highly correlated with marital satisfaction/ satisfaction with the relationship. The results of the correlation analyses are presented in Table 4.

\section{DESCRIPTIVE CHARACTERISTICS OF THE SIRRS-R}

The Polish version of the SIRRS-R shows good psychometric properties (see Table 5). Cronbach's $\alpha$ coefficient was calculated in order to estimate the internal consistency of the instrument. The whole scale reliability measured with Cronbach's $\alpha$ is .94, while for the individual subscales the alphas range from .85 to .92 . The total score of the SIRRS-R ranges between 12 and 100. As the score increases, support received from the partner in the intimate relationship also increases.

Table 3

Intercorrelation matrix for SIRRS-R and subscales

\begin{tabular}{|c|c|c|c|c|}
\hline & Factor 1 & Factor 2 & Factor 3 & Factor 4 \\
\hline Factor 1. Informational support & 1 & & & \\
\hline Factor 2. Physical comfort & $.51^{* *}$ & 1 & & \\
\hline Factor 3. Emotional and esteem support & $.74^{* *}$ & $.58^{* *}$ & 1 & \\
\hline Factor 4. Instrumental or tangible support & $.64^{* *}$ & $.45^{* *}$ & $.66^{* *}$ & 1 \\
\hline SIRRS-R & $.89^{* *}$ & $.72 * *$ & $.91^{* *}$ & $.81^{* *}$ \\
\hline
\end{tabular}

Table 4

Correlation between SIRRS-R and Received Partner Support (BSSS), and Satisfaction with Marriage/Relationship (FLZ)

\begin{tabular}{lcc}
\hline SIRRS-R & $\begin{array}{c}\text { Actually Received } \\
\text { Partner Support BSSS }\end{array}$ & $\begin{array}{c}\text { Satisfaction with } \\
\text { Marriage/Partnership FLZ }\end{array}$ \\
\hline SIRRS-R (total score) & $.81^{* *}$ & $.81^{* *}$ \\
Informational support & $.73^{* *}$ & $.74^{* *}$ \\
Physical comfort & $.54^{* *}$ & $.56^{* *}$ \\
Emotional/esteem support & $.77^{* *}$ & $.73^{* *}$ \\
Instrumental/tangible support & $.67^{* *}$ & $.71^{* *}$ \\
\hline Note. ${ }^{* *} p<.01$. & &
\end{tabular}


Table 5

Descriptive statistics for the SIRRS-R: Cronbach's $\alpha$, means, standard deviations

\begin{tabular}{lccccccc}
\hline Scale/subscale & $N$ (items) & $\alpha$ & $M$ & SEM & SD & Min & Max \\
\hline SIRRS-R (total score) & 25 & .94 & 68.97 & .71 & 17.18 & 12.00 & 100.00 \\
Informational support & 8 & .87 & 21.33 & .24 & 5.96 & 3.00 & 32.00 \\
Physical comfort & 4 & .92 & 12.13 & .15 & 3.77 & 0.00 & 16.00 \\
Emotional/esteem support & 8 & .88 & 22.71 & .25 & 6.15 & 2.00 & 32.00 \\
Instrumental/tangible support & 5 & .85 & 12.78 & .18 & 4.40 & 0.00 & 20.00 \\
\hline
\end{tabular}

\section{DISCUSSION}

The major aim of the study was to evaluate the psychometric properties of the Polish version of the Support in Intimate Relationships Rating Scale - Revised (SIRRS-R) developed by Barry et al. (2009). The results of our analysis are compatible with the existing multidimensional conceptualization of received partner support developed by Cutrona and Russell (1990) and modified by Barry et al. (2009). We evaluated the psychometric properties of the SIRRS-R by conducting a confirmatory factor analysis and comparing three structural hypothetical models, and by testing internal consistency and convergent validity of the instrument. First, the unidimensional or one-factor model was tested. Although this model had a good fit to the data, we made an assumption that the models under comparison should be supported theoretically. On the basis of the fit indices, the four-factor model was considered to provide a good explanation of the sample data. This model was based on the structure proposed by Barry et al. (2009), who distinguished the following factors: (1) informational support, (2) physical comfort, (3) esteem/emotional support and (4) instrumental or tangible support.

However, we observed that the intercorrelations between factor 1 (informational support) and factor 3 (emotional/esteem support) were too strong (.085). Factor intercorrelations above .80 or .85 imply poor discriminant validity and suggest that a more parsimonious solution could be obtained (Brown, 2006 , p. 32). We concluded that the four factors may show no significant predictive utility above and beyond that of a general higher-order SIRRS-R factor in terms of their association with other outcome variables. All factors were intercorrelated, so we decided to run a single higher-order factor analysis (Brown, 2006). The second-order factor was hypothesized to explain all the covariance among the first-order factors. A higher-order model can be tested when it is justified theoretically to account for relations among lower-order factors (Byrne, 2005). The third model showed that a higher-order SIRRS-R factor explained a high percentage of variance for scores in informa- tional and emotional/esteem support, and moderate for instrumental/tangible support and physical comfort. The good second-order factor loadings indicated that the first-order factors were adequately explained by the higher-order factor. The obtained results suggest that the SIRRS-R in our adaption was well characterized by the second-order factor model. Moreover, the fit indices remain basically the same in both the first- and the second-order model (no discrepancy in CFI, TLI, RMSEA between 4 factors in model 2 and the second-order factor in model 3). The latent structure of this questionnaire is predicted to be characterized by four first-order factors. The four factors are presumed to be intercorrelated.

Another point which requires further interpretation is related to the question why two factors (factor 1 - informational support and factor 3 - emotional/esteem support) showed such a strong relationship between each other. The answer can be sought in language differences caused by different cultures. Some items may have been differently understood in the Polish sample than the American one. For example, item number 8 ("Inferred how I was feeling about a situation" - Informational support) and item number 19 ("Said he/she would feel the same way in my situation" - Emotional/esteem support) may seem similar to Polish participants. Therefore, cross-cultural research to establish invariance across cultures is needed.

Our results are to a great degree consistent with the findings reported in the original study by Barry et al. (2009). The confirmatory factor analysis results generally supported the factorial structure of the original version of the SIRRS-R proposed by Barry et al. (2009). In our study the standardized factor loadings for all items were positive, high, and statistically significant, ranging from .64 to .88. The factor loadings reported by Barry et al. (2009) were generally similar, ranging from .59 to 1.00 . Some differences emerged when analyzing factor intercorrelations. In research done on the American sample the factor correlations were slightly lower, ranging from .45 to .65 , than in our sample (from .51 to .74 ). The differences may largely be attributable to the different 
meanings in the two languages resulting from cultural differences, as well as the selection of subjects for the sample (for example, there were significantly more men in the American sample as compared to the Polish sample).

With regard to factorial reliability, the findings suggested that the Polish version of the SIRRS-R shows high reliability. The Cronbach's $\alpha$ reliability for the whole scale is .94 , while for the individual subscales alphas ranged from .85 to .92 . These results correspond closely with the findings reported by the authors of the original version of the SIRRS-R: for the individual subscales, alphas ranged from .86 to .92 (Barry et al., 2009).

Convergent validity of the Polish version of the SIRRS-R is corroborated by the positive, high correlation of global perceptions of support received from an intimate partner, measured by the SIRRS-R with actual received social support measured by BSSS. Moreover, the support received from the partner measured by means of the SIRRS-R correlated highly with marital/relationship satisfaction, which means that our findings provide evidence of the criterion validity of scores. Generally, the results of the current research indicate satisfactory psychometric properties of the Polish version of the SIRRS-R. For researchers it is also important how much time it takes to complete the questionnaire. The participants found the SIRRS-R questionnaire relevant, clear and easy to manage, taking about 8-10 minutes to finish. And, what is important, results for the invariance tests indicated equivalence across participants from married couples and informal relationships.

When interpreting the results obtained, it is worth emphasizing that our research confirms the validity of adopting a multidimensional model of social support used by Cutrona and Russell (1990) in their consideration of support in intimate relationships. Our analyses replicate psychometrically the findings by Barry et al. (2009). Three types of support (emotional and esteem support, informational support, instrumental or tangible support) are consistent with those described by Cutrona and Russell (1990). Additionally, our research provided evidence for yet another type of partner support called physical comfort, described by Barry et al. (2009) in their four-factor model. As the authors wrote, "the emergence of a physical comfort dimension distinct from emotional support may lead researchers to examine how nonverbal expressions of support play a unique role in coping efforts relative to verbal forms of support" (Barry et al., 2009, pp. 55-56). The multidimensionality of the SIRRS-R offers interesting options for research on the diversity of social support in intimate relationships; it also opens new possibilities for developing psychological counseling for couples. Compared with the existing measures, the SIRRS-R is helpful when exploring more nuanced types of partner support in intimate relationships. For example, using the Received Social Support Scale of the BSSS it is possible to measure received support from other people, not necessarily from the partner (see Łuszczyńska et al., 2006). In turn, the questionnaire developed by Mandal and Moron (2017 - the Support in Marriage and Intimate Relationships Questionnaire [in Polish: Kwestionariusz Wsparcia w Matżenstwie $i$ Bliskich Zwiazkach]) is another tool available to measure the support received from a partner. However, there is a problem of comparability of the Polish results and results obtained in other countries. Mandal and Moroń (2017) carried out adaptation of the original 48-item version of the SIRRS questionnaire developed by Dehle et al. (2001) but significantly shortened the questionnaire (22 items) and labeled the types of support received from the partner according to their own conceptualization.

The current study has some limitations that require further research. First, the group of participants consisted mostly of women (around 70\%). Another constraint related to the sample was the relatively low diversity in the sample characteristics with respect to education level. A majority of participants had university education. These limitations reduce the generalizability of the results and should be addressed in future studies on a more representative sample of people in intimate relationships. This means that both greater male participation and diversity in terms of education level should be ensured. Testing for equivalence of measures using the SIRRS-R instrument is an important issue, and future research should focus on measurement invariance across gender and couple types (e.g. short vs. long relationship experience), with particular emphasis on cross-cultural research.

Even with these limitations and suggestions as to future research, the present results provide empirical evidence that the SIRRS-R questionnaire has good psychometric properties and may provide interesting information about partner support in intimate relationships. The adaptation and validation of the SIRRS-R could be useful to conduct studies targeting Polish speaking people in close relationships. In addition, the measure with good reliability and construct validity will be useful for future research and allow cross-cultural studies.

\section{CONCLUSIONS}

The Polish version of the SIRRS-R questionnaire, which closely corresponds to the English version, is a convenient instrument to assess social support received in intimate relationships, with good psychometric properties. The multidimensional support model allows for estimation of four types of support: emotional and esteem support, informational support, instrumental or tangible support and physical 
comfort. The tool can be useful in research on the need to assess various aspects of support received from the partner in different contexts of intimate relationships and family life associated with stress. The psychometric properties of the SIRRS-R indicate that the instrument can be applied to test partner support in both married couples and informal relationships.

\section{RefERENCES}

Acitelli, L. K., \& Antonucci, T. C. (1994). Gender differences in the link between marital support and satisfaction in older couples. Journal of Personality and Social Psychology, 67, 688-698. https://doi. org/10.1037/0022-3514.67.4.688

Amato, P. R. (2000). The consequences of divorce for adults and children. Journal of Marriage and Family, 62, 1269-1287. https://doi.org/10.1111/j.17413737.2000.01269.x

Barnett, D., Clements, M., Kaplan-Estrin, M., \& Fialka, J. (2003). Building new dreams: Supporting parents' adaptation to their child with special needs. Infants and Young Children, 16, 184-200.

Barry, R., Bunde, M., Brock, R. L., \& Lawrence, E. (2009). Validity and utility of a multidimensional model of received support in intimate relationships. Journal of Family Psychology, 23, 48-57. https://doi.org/10.1037/a0014174

Bedyńska, S., \& Cypryańska, M. (2013) (eds.). Statystyczny drogowskaz 1 . Praktyczne wprowadzenie do wnioskowania statystycznego [Statistical signpost 1. Practical introduction to statistical reasoning]. Warsaw: Wydawnictwo Akademickie Sedno.

Brock, R. L., \& Lawrence, E. (2009). Too much of a good thing: Underprovision versus overprovision of partner support. Journal of Family Psychology, 23, 181-192. https://doi.org/10.1037/a0015402

Brock, R. L., O'Hara, M. W., Hart, K. J., McCabe, J. E., Williamson, J. A., Laplante D. P., Yu C., \& King, S. (2014). Partner support and maternal depression in the context of the lowa Floods. Journal of Family Psychology, 28, 832-843. https://doi.org/10.1037/ fam0000027

Brown, T. A. (2006). Confirmatory factor analysis for applied research. New York: The Guilford Press.

Buszman, K., \& Przybyła-Basista, H. (2017). Polska Adaptacja Wielowymiarowej Skali Spostrzeganego Wsparcia Społecznego [The Polish Adaptation of The Multidimensional Scale of Perceived Social Support]. Polskie Forum Psychologiczne, 22, 581-599.

Byrne, B. M. (2005). Factor analytic models: Viewing the structure of an assessment instrument from three perspectives. Journal of Personality Assessment, 85, 17-32. https://doi.org/10.1207/s15327752 jpa8501_02
Chodkiewicz, J. (2009). Adaptacja polska Kwestionariusza Zadowolenia z Życia (FLZ) [Polish adaptation of Life Satisfaction Questionnaire]. Studia Psychologiczne, 47, 5-21.

Collins, N. L., Dunkel-Schetter, C., Lobel, M., \& Scrimshaw, S. C. (1993). Social support in pregnancy: Psychosocial correlates of birth outcomes and postpartum depression. Journal of Personality and Social Psychology, 65, 1243-1258. https://doi.org/10. 1037/0022-3514.65.6.1243

Cohen, S. (2004). Social relationships and health. American Psychologist, 59, 676-684. https://doi. org/10.1037/0003-066X.59.8.676

Cohen, S., \& Wills, T. A. (1985). Stress, social support, and the buffering hypothesis. Psychological Bulletin, 98, 310-357. https://doi.org/10.1037/0033-2909. 98.2.310

Cutrona, C. E. (1996a). Social support in couples. Thousand Oaks, CA: Sage.

Cutrona, C. E. (1996b). Social support as a determinant of marital quality. In G. R. Pierce, B. R. Sarason, \& I. G. Sarason (Eds.), Handbook of social support and the family (pp. 173-194). New York: Springer.

Cutrona, C. E., \& Russell, D. W. (1990). Type of social support and specific stress: Toward a theory of optimal matching. In I. G. Sarason, B. R. Sarason, \& G. R. Pierce (Eds.), Social support: an interactional view (pp. 319-366). New York: Wiley.

Cutrona, C. E., Russell, D., \& Rose, J. (1986). Social support and adaptation to stress by the elderly. Journal of Psychology and Aging, 1, 47-54. https:// doi.org/10.1037/0882-7974.1.1.47

Dehle, C., Larsen, D., \& Landers, J. E. (2001). Social support in marriage. The American Journal of Family Therapy, 29, 307-324. https://doi.org/10.1080/ 01926180152588725

Dickerson, S. S., \& Zoccola, P. M. (2011). Toward a biology of social support. In S. J. Lopez \& C. R. Snyder (Eds.), The Oxford handbook of positive psychology (pp. 519-526). New York: Oxford University Press.

Dunkel-Schetter, C., \& Bennett, T. L. (1990). Differentiating the cognitive and behavioral aspects of social support. In B. R. Sarason, I. G. Sarason, \& G. R. Pierce (Eds.), Social support: an interactional view (pp. 267-296). New York: Wiley.

Dunkel-Schetter, C., Sagrestano, L. M., Feldman, P., \& Killingsworth, C. (1996). Social support and pregnancy. In G. R. Pierce, B. R. Sarason, \& I. G. Sarason (Eds.), Handbook of social support and the family (pp. 375-412). New York: Plenum Press.

Feeney, B. C., \& Collins, N. (2015). New look at social support: a theoretical perspective on thriving through relationships. Personality and Social PsychologyReview, 19,113-147.https://doi.org/10.1177/ 1088868314544222

Findler, L., Jacoby, A. K., \& Gabis, L. (2016). Subjective happiness among mothers of children with disabilities: The role of stress, attachment, guilt and social 
support. Research in Developmental Disabilities, 55, 44-54. https://doi.org/10.1016/j.ridd.2016.03.006

Gardner, K. A., \& Cutrona, C. E. (2004). Social support communication in families. In A. L. Vangelisti (Ed.), Handbook of family communication (pp. 495512). Mahwah, NJ: Lawrence Erlbaum Associates.

Haber, M. G., Cohen, J. L., Lucas, T., \& Baltes, B. B. (2007). The relationship between self-reported received and perceived social support: a meta-analytic review. American Journal Community Psychology, 39, 133-144. https://doi.org/10.1007/s10464-007-9100-9

Hornowska, E., \& Paluchowski, W. J. (2004). Kulturowa adaptacja testów psychologicznych [Cultural adaptation of psychological tests]. In J. M. Brzeziński (Ed.), Metodologia badań psychologicznych. Wybór tekstów [Methodology of psychological research. A selection of texts] (pp. 151-191). Warsaw: Wydawnictwo Naukowe PWN.

Ilska, M., \& Przybyła-Basista, H. (2017). Partner support as a mediator of the relationship between prenatal concerns and psychological well-being in pregnant women. Health Psychology Report, 5, 285-295. https://doi.org/10.5114/hpr.2017.68235

Januszewski, A. (2011). Modele równań strukturalnych w metodologii badań psychologicznych. Problematyka przyczynowości w modelach strukturalnych i dopuszczalność modeli [Structural Equation Models in the methodology of psychological research. Problems of causality in structural models and model acceptability]. Studia z Psychologii w KUL, 17, 213-245.

Kiecolt-Glaser, J. K., \& Newton, T. (2001). Marriage and health: His and hers. Psychological Bulletin, 127, 472-503. https://doi.org/10.1037/0033-2909.127.4.472

Knoll, N., \& Schwarzer, R. (2012). „Prawdziwych przyjaciół...”. Wsparcie społeczne, stres, choroba i śmierć ["A friend in need is a friend indeed." Social support, stress, illness and death]. In H. Sęk \& R. Cieślak (Eds.), Wsparcie spoteczne, stres $i$ zdrowie [Social support, stress and health] (pp. 29-48). Warsaw: Wydawnictwo Naukowe PWN.

Kołodziej-Zaleska, A., \& Przybyła-Basista, H. (2016). Psychological well-being of individuals after divorce: The role of social support. Current Issues in Personality Psychology, 4, 206-216. https://doi. org/10.5114/CIPP.2016.62940

Kózka, A., \& Przybyła-Basista, H. (2018). Perceived stress, ego-resiliency, and relational resources as predictors of psychological well-being in parents of children with Down syndrome. Health Psychology Report, 6, 50-59. https://doi.org/10.5114/ hpr.2018.71212

Kurdek, L. (2005). Gender and marital satisfaction early in marriage: a growth curve approach. Journal of Marriage and Family, 67, 68-84. https://doi. org/10.1111/j.0022-2445.2005.00006.x

Lawrence, E., Bunde, M., Barry, R. A., Brock, R. L., Sullivan, K. T., Pasch, L. A., White, G. A., Dowd, C. E.,
\& Adams, E. E. (2008). Partner support and marital satisfaction: Support amount, adequacy, provision, and solicitation. Personal Relationships, 15, 445-463. https://doi.org/10.1111/j.1475-6811.2008.00209.x

Luszczynska, A., Boehmer, S., Knoll, N., Schulz, U., \& Schwarzer, R. (2007). Emotional support for men and women with cancer: Do patients receive what their partner provide? International Journal of Behavioral Medicine, 14, 156-163. https://doi. org/10.1007/BF03000187

Łuszczyńska, A., Kowalska, M., Mazurkiewicz, M., \& Schwarzer, R. (2006). Berlin Social Support Scales (BSSS): Polish version of BSSS and preliminary results on its psychometric properties. Studia Psychologiczne, 44, 17-27.

Maliszewska, K., Bidzan, M., Świątkowska, M., \& Preis, K. (2016). Personality type, social support and other correlates of risk for affective disorders in early puerperium. Ginekologia Polska, 87, 814-819.

Mandal, E., \& Moroń, M. (2017). Kwestionariusz Wsparcia w Małżeństwie i Bliskich Związkach [Support in Marriage and Intimate Relationship Questionnaire]. Przeglad Psychologiczny, 60, 399-417.

Melrose, K. L., Brown, G. D. A., \& Wood, A. M. (2015). When is received social support related to perceived support and well-being? When it is needed. Personality and Individual Differences, 77, 97-105. https://doi.org/10.1016/j.paid.2014.12.047

Mîndrilă, D. (2010). Maximum likelihood (ML) and diagonally weighted least squares (DWLS) estimation procedures: a comparison of estimation bias with ordinal and multivariate non-normal data. International Journal of Digital Society, 1, 60-66. https://doi.org/10.20533/ijds.2040.2570.2010.0010

Negron, R., Martin, A., Almog, M., Balbierz, A., \& Howell, E. A. (2013). Social support during the postpartum period: Mothers' views on needs, expectations, and mobilization of support. Maternal and Child Health Journal, 17, 616-623. https://doi.org/10.1007/ s10995-012-1037-4.

Ogińska-Bulik, N. (2013). The role of social support in posttraumatic growth in people struggling with cancer. Health Psychology Report, 1, 1-8. https:// doi.org/10.5114/hpr.2013.40464

Prati, G., \& Pietrantoni, L. (2010). The relations of perceived and received social support to mental health among first responders: a meta-analytic review. Journal of Community Psychology, 38, 403-417. https://doi.org/10.1002/jcop.20371

Rhemtulla, M., Brosseau-Liard, P., \& Savalei, V. (2012). When can categorical variables be treated as continuous? A comparison of robust continuous and categorical SEM estimation methods under suboptimal conditions. Psychological Methods, 17, 354-373. https://doi.org/10.1037/a0029315

Rini, C., Dunkel-Schetter, C., Hobel, C. J., Glynn, L. M., \& Sandman, C. A. (2006). Effective social support: antecedents and consequences of partner sup- 
port during pregnancy. Personal Relationships, 13, 207-229. https://doi.org/10.1111/j.1475-6811.2006. 00114.x

Rosseel, Y. (2012). lavaan: an R package for structural equation modeling. Journal of Statistical Software, 48, 1-36. https://doi.org/10.18637/jss.v048.i02

Scholz, U., Ochsner, S., Hornung, R., \& Knoll, N. (2013). Does social support really help to eat a low-fat diet? Main effects and gender differences of received social support within the Health Action Process Approach. Applied Psychology: Health and Well-being, 5, 270-290. https://doi.org/10.1111/ aphw. 12010

Schulz, U., \& Schwarzer, R. (2003). Soziale Unterstützung bei der Krankheitsbewältigung: Die Berliner Social Support Skalen (BSSS) [Social support in coping with illness: The Berlin Social Support Scales (BSSS)]. Diagnostica, 49, 73-82. https://doi. org/10.1026//0012-1924.49.2.73

Schwarzer, R., \& Knoll, N. (2007). Functional roles of social support within the stress and coping process: a theoretical and empirical overview. International Journal of Psychology, 42, 243-252. https://doi.org/10.1080/00207590701396641

Schwarzer, R., \& Leppin, A. (1991). Social support and health: a theoretical and empirical overview. Journal of Social and Personal Relationships, 8, 99-127. https://doi.org/10.1177/0265407591081005

Sullivan, K. T., Pasch, L. A., Eldridge, K. A., \& Bradbury, T. N. (1998). Social support in marriage: Translating research into practical applications for clinicians. The Family Journal, 6, 263-271. https://doi.org/10.1177/1066480798064002

Uchino, B. N. (2006). Social support and health: a review of physiological processes potentially underlying links to disease outcomes. Journal of Behavioral Medicine, 29, 377-387. https://doi. org/10.1007/s10865-006-9056-5

Uchino, B. N. (2009). Understanding the links between social support and physical health: a lifespan perspective with emphasis on the separability of perceived and received support. Perspective on Psychological Science, 4, 236-255. https://doi. org/10.1111/j.1745-6924.2009.01122.x

Uchino, B. N., Carlisle, M., Birmingham, W., \& Vaughn, A. A. (2011). Social support and the reactivity hypothesis: Conceptual issues in examining the efficacy of received support during acute psychological stress. Biological Psycholology, 86, 137-142. https://doi.org/10.1016/j.biopsycho.2010.04.003 


\title{
APPENDIX 1
}

\author{
SKALA OCENY WSPARCIA W BLISKICH ZWIĄZKACH (SIRRS-R) \\ [THE SUPPORT IN INTIMATE RELATIONSHIPS RATING SCALE - REVISED]
}

(SIRRS-R by Barry, Bunde, Brock, \& Lawrence, 2009, Polish adaptation by Ilska, \& Przybyła-Basista)

Pomyśl o różnych sytuacjach stresowych, problemach, kłopotach, wyzwaniach, z którymi mierzyłaś/-łeś się w okresie ostatniego miesiąca. A teraz pomyśl o relacjach, jakie miałaś/-łeś w tym czasie z Twoim partnerem/partnerką, kiedy doświadczałaś/-łeś tych sytuacji stresowych lub problemów. Odnosząc się do każdego stwierdzenia, poniżej wskaż, tak dokładnie jak potrafisz, jak często Twój partner/partnerka zachowywał/-ła się w określony sposób.

[Think over the past month and the various stresses, hassles, problems or challenges you have faced. Now take a minute to think back to the interactions you have had over the past months with your partner when you were experiencing those stresses and problems. For each of the items below, indicate, as closely as you can, how frequently your partner did each of these behaviors.]

W ostatnim miesiącu, gdy czułam/-łem się zdenerwowana/-ny, zestresowana/-ny lub będąc w kłopocie z powodu różnych problemów lub trudnych sytuacji, jak często mój partner/partnerka...

[ In the past month, when I was feeling upset, stressed or hassled by some problem or difficult situation...]
Jak często to się zdarzało?

[How frequently did this happen?]

\begin{tabular}{|c|c|c|c|c|}
\hline $\begin{array}{l}\frac{1}{0} \\
\sum_{0}^{0} \\
\frac{0}{2} \\
.00 \\
z\end{array}$ & 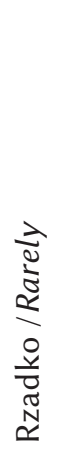 & 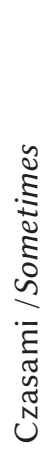 & 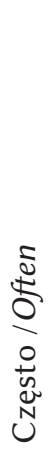 & 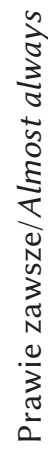 \\
\hline 0 & 1 & 2 & 3 & 4 \\
\hline 0 & 1 & 2 & 3 & 4 \\
\hline 0 & 1 & 2 & 3 & 4 \\
\hline 0 & 1 & 2 & 3 & 4 \\
\hline 0 & 1 & 2 & 3 & 4 \\
\hline 0 & 1 & 2 & 3 & 4 \\
\hline 0 & 1 & 2 & 3 & 4 \\
\hline 0 & 1 & 2 & 3 & 4 \\
\hline 0 & 1 & 2 & 3 & 4 \\
\hline
\end{tabular}

1. Dawał/-a mi wskazówki, jak poradzić sobie w danej sytuacji. [Gave me suggestions about how to handle a situation.] 2. Mówił/-a mi, jak rozwiązać problem albo poradzić sobie z sytuacją.
[Told me what to do to solve a problem or deal with a situation.]

3. Pomagał/-a mi spojrzeć na sytuację z innej perspektywy. [Helped me think about a situation in a new way.]

4. Uczył/-a mnie lub pokazywał/-a mi, jak coś zrobić, wykonać. [Taught me or showed me how to do something.]

5. Dzielił/-a się ze mną swoim osobistym doświadczeniem z sytuacji podobnej do mojej. [Shared a personal experience that was similar to my situation.]

6. Dzielił/-a się ze mną faktami lub informacjami dotyczącymi sytuacji, $\quad \begin{array}{llllll}0 & 1 & 2 & 3 & 4\end{array}$ z którą się zmagałam/-łem.

[Shared facts or information with me about a situation I was facing.]

7. Powiedział/-a mi swoimi słowami, jak rozumie tę sytuację, o której mu opowiedziałam/-łem.

[Restated what I had told him/her about a situation.]

8. Domyślił/-a się, jak się czułam w danej sytuacji. [Inferred how I was feeling about a situation.]

9. Przytulał/-a mnie. [Hugged me or cuddled with me.]

(Table continues) 
W ostatnim miesiącu, gdy czułam/-łem się zdenerwowana/-ny, zestresowana/-ny lub będąc w kłopocie z powodu różnych problemów lub trudnych sytuacji, jak często mój partner/partnerka...

[In the past month, when I was feeling upset, stressed or hassled by some problem or difficult situation...]

Jak często to się zdarzało?

[How frequently did this happen?]

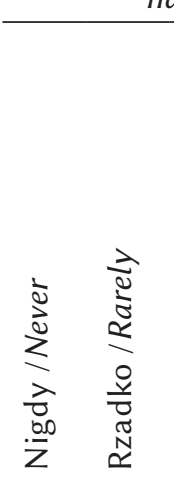

10. Całowat/-a mnie. [Kissed me.]

$\begin{array}{lllll}0 & 1 & 2 & 3 & 4 \\ 0 & 1 & 2 & 3 & 4 \\ 0 & 1 & 2 & 3 & 4 \\ 0 & 1 & 2 & 3 & 4\end{array}$

13. Mówił/-a mi, że wszystko będzie dobrze. [Told me everything would be OK.]

14. Powiedział/-a, że jego/jej zdaniem dobrze poradziłam/-łem sobie z sytuacją.

[Said he/she thought I handled a situation well.]

15. Był przekonany/Była przekonana, że poradzę sobie z sytuacją, w której się znalazłam/-łem.

[Expressed confidence in my ability to handle a situation.]

16. Mówił/-a dobre rzeczy o mnie. [Said good things about me.]

17. Mówił/-a, że to, jak się czuję, jest w porządku. [Said it was OK to feel the way I was feeling.]

18. Stawał/-a po mojej stronie, kiedy dyskutowano o mojej sytuacji. [Took my side when discussing my situation.]

19. Powiedział/-a, że czułby/czułaby się tak samo w tej sytuacji. [Said he/she would feel the same way in my situation.]

20. Powiedział/-a, że nie jestem winna/-y tej sytuacji. [Said I was not at fault for my situation.]

21. Zaoferował/-a konkretną, bezpośrednią pomoc w tej sytuacji. [Offered to do something to help me directly w/my situation.]

22. Pomógł/-ła mi w konkretny, bezpośredni sposób. [Did something to help me directly.]

23. Zaoferował/-a mi pomoc w pośredni sposób (np. zaoferował/-a, że wykona za mnie moje obowiązki).

[Offered to help me indirectly (e.g., offered to do my chores).]

24. Pomógł/-a mi w pośredni sposób (np. wykonał/-a za mnie moje obowiązki).

[Did something to help me indirectly (e.g., did my chores).

25. Zaoferował/-a, że zrobimy coś, abym poczuł/-a się lepiej. [Offered to do something with me to help me feel better.]

Informational support: 1, 2, 3, 4, 5, 6, 7, 8 .

Physical comfort: 9, 10, 11, 12.

Emotional and esteem support: 13, 14, 15, 16, 17, 18, 19, 20.

Instrumental or tangible support: 21, 22, 23, 24, 25. 